\title{
The Thirty Years' War: Europe's Tragedy
}

Robert Bireley S.J.

Loyola University Chicago, rbirele@luc.edu

Follow this and additional works at: https://ecommons.luc.edu/history_facpubs

Part of the History Commons

\section{Recommended Citation}

BIRELEY, ROBERT. 2012. "The Thirty Years' War: Europe's Tragedy." Renaissance Quarterly 65, no. 4: 1238-1240. http://www.jstor.org/stable/10.1086/669393.

This Book Review is brought to you for free and open access by the Faculty Publications and Other Works by Department at Loyola eCommons. It has been accepted for inclusion in History: Faculty Publications and Other Works by an authorized administrator of Loyola eCommons. For more information, please contact ecommons@luc.edu.

\section{(c) (i) $\ominus$}

This work is licensed under a Creative Commons Attribution-Noncommercial-No Derivative Works 3.0 License. (C) 2012 Renaissance Society of America 


\section{CHICAGO JOURNALS}

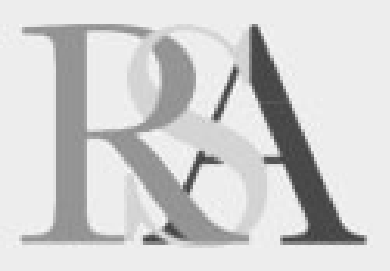

Peter H. Wilson. The Thirty Years' War: Europe's Tragedy

The Thirty Years' War: Europe's Tragedy by Peter H. Wilson

Review by: Robert Bireley

Renaissance Quarterly, Vol. 65, No. 4 (Winter 2012), pp. 1238-1240

Published by: The University of Chicago Press on behalf of the Renaissance Society of America

Stable URL: http://www.jstor.org/stable/10.1086/669393

Accessed: 15/05/2013 12:30

Your use of the JSTOR archive indicates your acceptance of the Terms \& Conditions of Use, available at

http://www.jstor.org/page/info/about/policies/terms.jsp

JSTOR is a not-for-profit service that helps scholars, researchers, and students discover, use, and build upon a wide range of content in a trusted digital archive. We use information technology and tools to increase productivity and facilitate new forms of scholarship. For more information about JSTOR, please contact support@jstor.org.

The University of Chicago Press and Renaissance Society of America are collaborating with JSTOR to digitize, preserve and extend access to Renaissance Quarterly. 
Peter H. Wilson. The Thirty Years' War: Europe's Tragedy.

Cambridge, MA: Belknap Press of Harvard University Press, 2011. xxiv + 998 pp. \$22.50. ISBN: 978-0-674-06231-3.

This lengthy volume represents a magnificent scholarly achievement based on the mastery of an enormous literature. It will become the standard account of the Thirty Years' War in English for years to come. But it does have flaws.

The author stresses the German character of the war. It was above all a "struggle over the political and religious order of Central Europe" (xxi). With a glance perhaps to Geoffrey Parker's Thirty Years War (2 ${ }^{\text {nd }}$ ed., 1997), he claims not to submerge it in a general account of war in the first half of the seventeenth century, yet he devotes considerable space to the principal states that intervened in the empire: Spain and France, Denmark and Sweden. Most accounts of the war, the author notes, tend to pass over quickly the last period from 1635 to the Peace of Westphalia in 1648. Wilson intends to provide "a more balanced coverage" (xxi) devoting proportionate space to the final thirteen years, important as they are for understanding the reasons for the failure to arrive earlier at a peace settlement and for their significance for the military historian.

The book has three main divisions. The first, "Beginnings," describes at length the origins of the long conflict reaching back to the Peace of Augsburg of 1555 and even beyond; the second, "Conflict," narrates more or less chronologically the story 
of the seemingly endless conflict; the third, "Aftermath," deals with the peace settlement and then turns to the war's short- and longterm effects and the experience of the war by soldiers and civilians, an area that has attracted considerable recent research. Throughout the author breaks his chapters neatly into titled sections that assist the reader.

Warning us not to oversimplify the war, the author makes three main arguments. Central to the war was the contest over the constitution of the Holy Roman Empire, and the author relates other aspects of the war to this basic struggle into which nearly all Europe was drawn. Secondly, the war was not primarily a religious war, though religion obviously played a major part in it, especially before 1635. The author distinguishes the militants and the moderates among both Catholics and Protestants. Thirdly, the war was not inevitable. Here he takes aim at those who argue that contemporary confessionalization led necessarily to the conflict. Rather, the war resulted from prolonged disputes, legal, political, and eventually military, over the proper interpretation of the Peace of Augsburg, the inability of imperial institutions to resolve these disputes, and the failure of efforts at composition of the differences between Catholics and Protestants. The war did contribute to the development of sovereign states in Europe but its most significant result for the author was the establishment of a relatively stable political order in the empire that lasted until the Napoleonic Wars. It did not solve all the empire's problems but it provided a constitutional structure that enabled successful solutions to be found. The settlement in Westphalia also resulted in a form of religious toleration more generous than found elsewhere, but a toleration rather of the three churches, Catholic, Lutheran, and Calvinist than a modern toleration of individual religious choice. The author cautions us not to see the peace as a step toward secularization. Altogether, he estimates, 1.2 million soldiers died, probably three from disease to each killed in action. General population losses were spread unevenly over the empire; in some areas the population of 1618 was not reached again until 1710-20. Government debts incurred during the war were in some cases still being paid in the nineteenth century.

Wilson displays an amazing knowledge of the geography of the empire as he describes the movements of armies and the battles in which they clashed. The author devotes a whole chapter near the start to the Turkish threat, and he draws attention regularly to the important influence on the war of events in southeastern Europe, a topic often overlooked in treatments of the Thirty Years' War. Cardinal Klesl receives due recognition for his role in the formation of imperial policy toward the Turks and for his eventually unsuccessful efforts to compose the differences between Catholics and Protestants in the empire on the eve of the war.

In any discussion of the religious character of the war, one must determine religious for whom: rulers or policymakers, soldiers, ordinary folk? One would like to have seen this topic analyzed more fully. And in such an ambitious work, some errors are bound to creep into the text. Wilson stresses the efforts of Lutheran Landgrave George of Hesse-Darmstadt to mediate the differences between Catholics 
and Protestants. But he exaggerates his role at the critical Electoral Convention of Regensburg in 1630. The "Hessian Points" that the Landgrave proposed for unofficial discussion found the support of neither moderates nor militants on either side of the confessional divide. When he was transferred to Rome in 1622 after his arrest by Archdukes Ferdinand and Maximilian in 1618, Cardinal Klesl was not condemned by a committee of cardinals. Rather, the Holy Office released him from prison and annulled the charges against him for lack of evidence. The Council of Trent was not "a council of cardinals" (26). Prince Eggenberg, Emperor Ferdinand's longtime principal minister did not resign in the early 1630s over differences regarding the Edict of Restitution and the war in Italy; he did threaten to do so. The author attributes to this writer a position regarding the goals of Emperor Ferdinand II in the empire that he does not hold.

Finally, this book is simply too long. It contains too many detailed accounts of too many battles, especially in the last phase of the war. The reader finds himself skipping over pages. But these shortcomings might be corrected in a second edition, and they certainly should not detract from the kudos that Professor Wilson deserves for his outstanding achievement.

ROBERT BIRELEY

Loyola University Chicago 